\title{
Entre objetos da ciência e vítimas de um holocausto negro: Humanização, agência e tensões classificatórias em torno das ossadas do sítio arqueológico Cemitério dos Pretos Novos
}

Simone Pondé Vassallo*

\section{Resumo}

Este artigo procura problematizar alguns agenciamentos de vestígios humanos a partir da análise do tratamento dado a ossadas encontradas em 1996, no subsolo de uma residência familiar, na região portuária do Rio de Janeiro. Inspirando-me nas obras de Bruno Latour e Michel Callon, procuro observar como se constrói progressivamente o fato científico de que esses ossos pertencem ao sítio arqueológico Cemitério dos Pretos Novos, destinado ao enterramento de africanos que morreram logo após o desembarque dos navios negreiros, entre fins do século XVIII e início do XIX. 0 objetivo do presente artigo consiste em analisar a produção do sítio arqueológico Cemitério dos Pretos Novos e os diversos procedimentos através dos quais as ossadas são convertidas ora em objetos de pesquisa a serem armazenados em laboratórios científicos, ora em testemunhas de um holocausto negro que devem ser expostas ao público no Memorial Pretos Novos. Busco analisar as tensões e ambiguidades classificatórias que surgem ao longo do processo que, simultaneamente, objetifica e humaniza as ossadas, tratando-as ao mesmo tempo como objetos de estudos científicos e laboratoriais e como testemunhas de um crime contra a humanidade.

\section{Palavras-chave}

Representações da escravidão. Vestígios humanos. Diáspora africana. Patrimônio arqueológico.

\section{Abstract}

This article approaches forms of managing human remains in the analysis of bones found, in 1996, under a family residence in the port region of Rio de Janeiro. Inspired by the works of Bruno Latour and Michel Callon, I examine how the scientific fact of these bones belonging to the archaeological site of Pretos Novos Cemetery - where Africans who died soon after the

* Simone Pondé Vassallo é professora adjunta do Departamento de Antropologia da Universidade Federal Fluminense (UFF). E-mail: simonepvassallo@gmail.com. 
landing of slave ships were buried, in the late 18th and early 19th centuries, - have being progressively produced. The aim is to examine the production of Pretos Novos Cemetery archaeological site and the procedures through which the bones were converted into research objects to be stored in scientific laboratories, or made witnesses of a black holocaust that must be exposed to the public eye at the Pretos Novos Memorial. The classificatory tensions and ambiguities arised during the process are discussed.

\section{Keywords}

Representations of slavery. Human remains. African diaspora. Archeological heritage.

\section{Introdução}

Este artigo procura problematizar alguns agenciamentos de vestígios humanos a partir da análise do tratamento dado a ossadas encontradas em 1996, no subsolo de uma residência familiar, na região portuária do Rio de Janeiro. Inspirando-me em Latour e Woolgar (1997) e Michel Callon (1986), procuro observar como se constrói progressivamente o fato científico de que esses ossos pertencem ao sítio arqueológico Cemitério dos Pretos Novos, destinado ao enterramento de africanos que morreram logo após o desembarque dos navios negreiros, entre fins do século XVIII e início do XIX 1 .

Retomo aqui as críticas de Latour à noção de "descoberta científica", como se certos objetos tivessem existência a priori e estivessem somente à espera da chegada do pesquisador para serem "descobertos". Acredito que a produção de um fato científico constitua um resultado, e não um ponto de partida da investigação (CALLON, 1986). Assim, não pretendo partir do que as ossadas "realmente seriam", mas sim daquilo em que elas vão

\footnotetext{
${ }^{1}$ Agradeço a Daniela Manica, Pedro Ferreira e Clarice Rios, pelas sugestões oferecidas no ST Antropologia e Antropocentrismos, debates, desafios e perspectivas, durante a VIa ReACT, de 16 a 19 de maio de 2017, na USP, São Paulo. Também agradeço à gentileza de Claudia Fonseca, pelas sugestões bibliográficas e por ter propiciado o contato com as demais autoras do presente dossiê, à contribuição de Felipe Berocan Veiga e Andrei Santos, respectivamente docente e discente do Departamento de Antropologia da Universidade Federal Fluminense, e por fim, à família Guimarães, à equipe de Reinaldo Tavares e aos demais informantes que tornaram este artigo possível.
} 
se transformando desde que são encontradas em 1996 e classificadas como o sítio arqueológico em questão.Em vez de tomar o social como dado, busco as "associações" que vão se formando progressivamente em torno das ossadas, os esforços em mantê-las e algumas de suas controvérsias (LATOUR, 2012).Para tanto, pretendo seguir a "vida social" dos ossos (APPADURAI, 2008) desde que foram desenterrados.

Acredito que as escavações arqueológicasnão apenas reproduzem o fato objetivo de que se trata de um sítio arqueológico, mas sim que elas o produzem. O objetivo do presente artigo consiste em analisar a produção do sítio arqueológico Cemitério dos Pretos Novos e os diversos procedimentos através dos quais as ossadas são convertidas ora em objetos de pesquisa a serem armazenados em laboratórios científicos, ora em testemunhas de um holocausto negro, que devem ser expostas ao público no Memorial Pretos Novos.Nesse sentido, a partir de uma "definição performativa" (Latour, 2012) do cemitério e suas ossadas, analiso as tensões e ambiguidades classificatórias que surgem ao longo do processo que simultaneamente objetifica e humaniza as ossadas, tratando-as ao mesmo tempo como objetos de estudos científicos e laboratoriais e como testemunhas de um crime contra a humanidade.

As tensões em tornodas ossadas só podem ser compreendidas num contexto recente mais amplo,que envolve, ao mesmo tempo, uma proliferação de representações da escravidão em museus e memoriais de diversos países;uma intensificação dospedidos de reparação para afrodescendentes e das políticas de ação afirmativa; e os pedidos de repatriamento de vestígios humanos de povos colonizados, armazenados em museus ou em laboratórios científicos, que atribuem "novos poderes aos velhos ossos" (VÉRANT, 2012) e põem em cheque as tradicionais representações dos "negros como objetos da ciência".

Na medida em que os que vivenciaram a escravidão já morreram e os que foram enterrados no Cemitério dos Pretos Novos não podem mais falar na primeira pessoa, coloca-se a questão de quem fala por eles e do que é dito. De acordo com Stephan Palmié (2010), temos assimuma mudança no status das lembranças da escravidão. Suas representações passam a ter uma relevância política e moral no presente, pois adquirem sentido dentro das atuais estruturas de privilégio e de desigualdades sociais e raciais, ao mesmo tempo que dão legitimidade às lutas contra essas mesmas estruturas. Entre os efeitos dessas novas formas de se relacionar com o passado da escravidão 
temos, por um lado, a transformação da memória numa propriedade corporativa de coletividades mnemônicas que a reivindicam (PALMIÉ, 2010) e a pensam como uma "propriedade inalienável" (WEINER, 1992). Por outro, temos a grande valorização da arqueologia da diáspora africana e a consequente projeção dos seus arqueólogos. É em meio a essa trama que as diferentes representações das ossadas dos Pretos Novos entram em disputa e procuram se estabilizar.

Privilegio aqui a atuação dos arqueólogos envolvidos nas escavações e, em menor grau, a da família que encontrou as ossadas e de integrantes do movimento negro, procurando compreender como ocorre a estabilização da identidade preconizada para as ossadas e quais as suas principais controvérsias.

A reflexão que dá origem a este artigo é fruto de uma pesquisa de campo que realizo desde 2010 no sítio arqueológico e que me permitiu acompanhar a criação do Memorial dos Pretos Novos, em 2011, bem como observar alguns momentos das escavações arqueológicas realizadas no local em 2012 e em 2017. Também foram realizadas entrevistas, consultas ao arquivo do IPHAN e visitas ao laboratório onde parte das ossadas está armazenada.

\section{1) A "descoberta" das ossadas e 0 "ponto de passagem obrigatório"}

Em janeiro de 1996, no primeiro dia de obras de uma antiga residência no bairro da Gamboa, na zona portuária do Rio de Janeiro, foi encontrada uma profusão de ossos que foram identificados como humanos e que desencadearam uma série de ações. O casal Guimarães, proprietário do recém-adquirido imóvel, buscava lá se estabelecer com suas três filhas então adolescentes. A família se considera branca, é dona de uma firma de dedetização nas imediaçõese declara que até então não tinha muito contato com as práticas culturais e nem com a história dos afro-brasileiros. Intrigados com a enorme quantidade de ossos que praticamente jorravam dos buracos do subsolo escavados pelos pedreiros, Merced e Petrúcio Guimarães começaram a se informar na vizinhança sobre os possíveis motivos daquelaestranha presença. Num primeiro momento, pensaram tratar-se de uma chacina. Mas, em conversa com uma liderança local, que, nos anos 1980, havia se envolvido com um projeto de valorização da história da região portuária com vistas a impedir a demolição do 
antigo casario ${ }^{2}$, foram informados de que as ossadas deveriam pertencer ao que passou a ser progressivamente chamado de Cemitério dos Pretos Novos pelos atores diretamente envolvidos. A partir dessa classificação inicial, realizada por um morador do bairro que havia desenvolvido uma sensibilidade histórica, temos uma primeira conversão simbólica das ossadas, em que a elas é conferido um valor patrimonial.

A partir de então, o casal informa as autoridades municipais, e o assunto chega ao setor de arqueologia do DGPC (Divisão Geral de Patrimônio Cultural), órgão da Prefeitura responsável pelo patrimônio do município. A arqueóloga do DGPC, Eliana Teixeira de Carvalho, é enviada ao local junto com a bioantropóloga Lilia Cheuiche Machado, do Instituto de Arqueologia Brasileira (IAB). Os primeiros ofícios que circularam entre o DGPC e o IPHAN referem-se apenas à "descoberta de ossos humanos" (ofício de Eliana Teixeira, em 15 de Janeiro de 1996). Ao chegarem à residência da família Guimarães, as duas pesquisadoras constatam um "grande volume de terra e entulho" (idem) e caixas e tampas de papelão "repletas de ossos, correspondendo a vários indivíduos, em total mistura e desordem anatômica" (idem). Nos relatos de Lilia Cheuiche:

"na medida em que [os operários] perfuravam o solo, com o uso de pás e picaretas, uma grande quantidade de ossos humanos era fragmentada, misturando-se com a terra durante a remoção do entulho para a superfície. Os elementos ósseos, extremamente danificados, foram assim incorporados ao entulho acumulado ao redor dos buracos que haviam sido abertos". (MACHADO, 2006, p.1).

Junto com os ossos, havia também "outras classes de vestígios, tais como cerâmica neobrasileira e colonial, louça, objetos de adorno e de metal", que "durante cerca de dois meses foram cuidadosamente resgatados do entulho das obras" (MACHADO, 2006, p.1). Para Eliana Teixeira, os "elementos

\footnotetext{
${ }^{2}$ As atividades de valorização do bairro afirmando-o como de "interesse histórico" para impedir as demolições resultaram na elaboração do Projeto SAGAS, que deu origem à legislação municipal que protege inúmeros imóveis dos bairros Saúde, Gamboa e Santo Cristo (lei n. 971, de 4 de maio de 1987). É nesse contexto que as informações sobre a existência de um mercado de escravos e do Cemitério dos Pretos Novos começam a ser veiculadas, sobretudo através da publicação sobre a história dos bairros Saúde, Gamboa e Santo Cristo (CARDOSO et al., 1987).
} 
ósseos" estão em "mau estado de conservação, dadas as circunstâncias fortuitas da descoberta", devendo ser alvo de um resgate emergencial em meio aos sedimentos de entulho. $\mathrm{O}$ acervo deverá ser transportado em cerca de 15 caixas de papelão (TEIXEIRA, 1996).

Temos assim um momento inicial em quese mesclam terra, entulho, canos, tubos, alicerces, ossadas, operários e seus instrumentos, louça, cerâmica, metal, material de construção, caixas de papelão, uma casa em obras e integrantes de uma família intrigados com uma presença humana não planejada. Esse momento da descoberta, "cheio de som e fúria, de desordem e de paixões" (LATOUR; WOOLGAR, 1997, p.32), ainda está muito distante do contexto "calmo e ordenado" da justificação (idem), quando o fato científico de que aquele local é o Cemitério dos Pretos Novos já está estabelecido e estabilizado.

Num primeiro momento, as afirmações das pesquisadoras e das autoridades municipais envolvidas ainda são relativamente vagas: "podemos concluir que se trata de um antigo cemitério..." (ofício de Eliana Teixeira em 15 de Janeiro de 1996,). A arqueóloga do IPHAN, Rosana Najar, em memorando de 04/03/96, fala na "descoberta fortuita de um provável cemitério" que "poderia ser o Cemitério dos Pretos Novos" [grifos meus]. Em ofício de 11/03/96, o Coordenador da $6^{a}$ CR do IPHAN já classifica o local como um "sítio arqueológico" e informa que o mesmo "já se encontra protegido pelo IPHAN".

Ainda que baseada em algumas incertezas, essa primeira definição já é suficiente para determinar os novos rumos e redes dos vestígios humanos. Entendidos como artefatos arqueológicos, os ossos encontrados são então coletados, limpos, triados, identificados, ensacados, etiquetados, encaminhados ao IAB e guardados em gavetas e caixas, onde permanecem até hoje. A partir dessa nova classificação, os ossos são considerados ao mesmo tempo "patrimônio" e "objetos da ciência", e são investidos de um grande valor universal. Atuam como "arquivos da humanidade" e "testemunhos da história" que podem fornecer preciosas informações científicas sobre as migrações, as doenças e a evolução humanas (ARANDA, 2014). O corpo humano se inscreve aqui num "paradigma evidencial" (CROSSLAND, 2009) a partir do qual ele é suscetível de fornecer cientificamente importantes provas de fatos pregressos. Armazenados nos sacos plásticos e caixas do IAB, eles aguardam pacientemente o despertar do interesse de pesquisadores, para que, retirados mais uma vez do seu descanso eterno, sejam enviados a laboratórios onde serão devidamente 
escrutinados e analisados, para responder a possíveis questões: de onde vêm esses indivíduos e o que eles nos informam sobre as migrações humanas? São eles homens ou mulheres, e que idade têm? Quais os seus hábitos alimentares? De quais doenças teriam sido acometidos? Quais as peculiaridades com que foram enterrados?

Sacos plásticos do IAB contendo partes de ossos coletadas no Cemitério dos Pretos Novos em 1996.

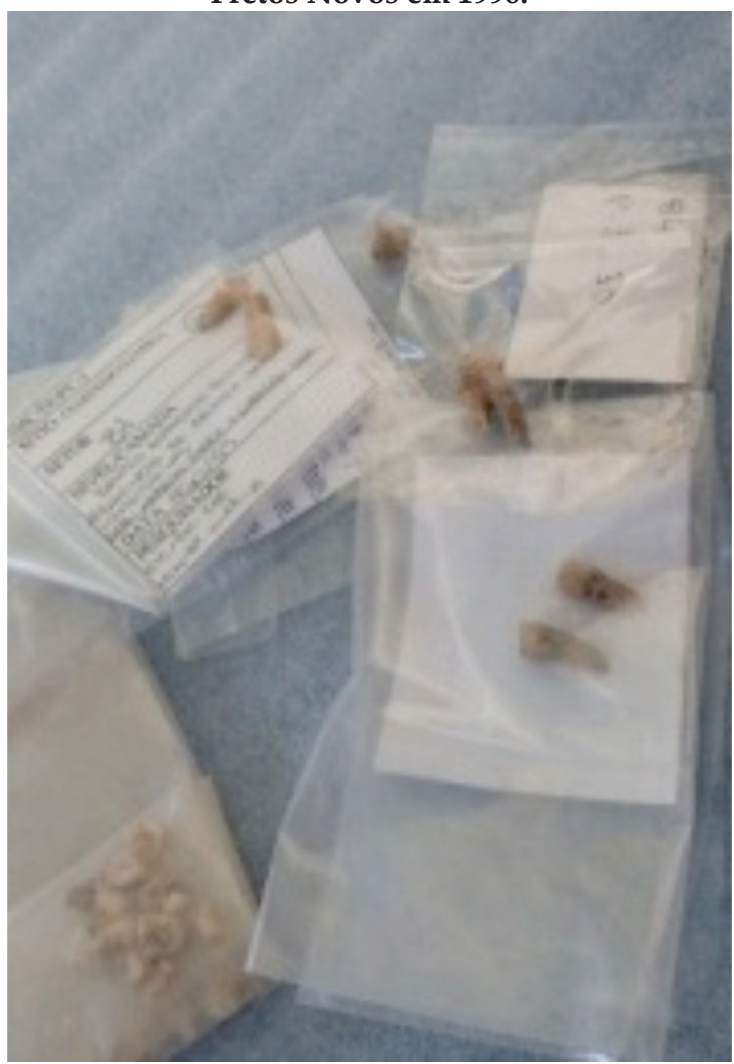

Foto: Tirada por Simone Vassallo. 
Caixas do IAB que armazenam os sacos plásticos contendo as ossadas do Cemitério dos Pretos Novos, coletadas em 1996.

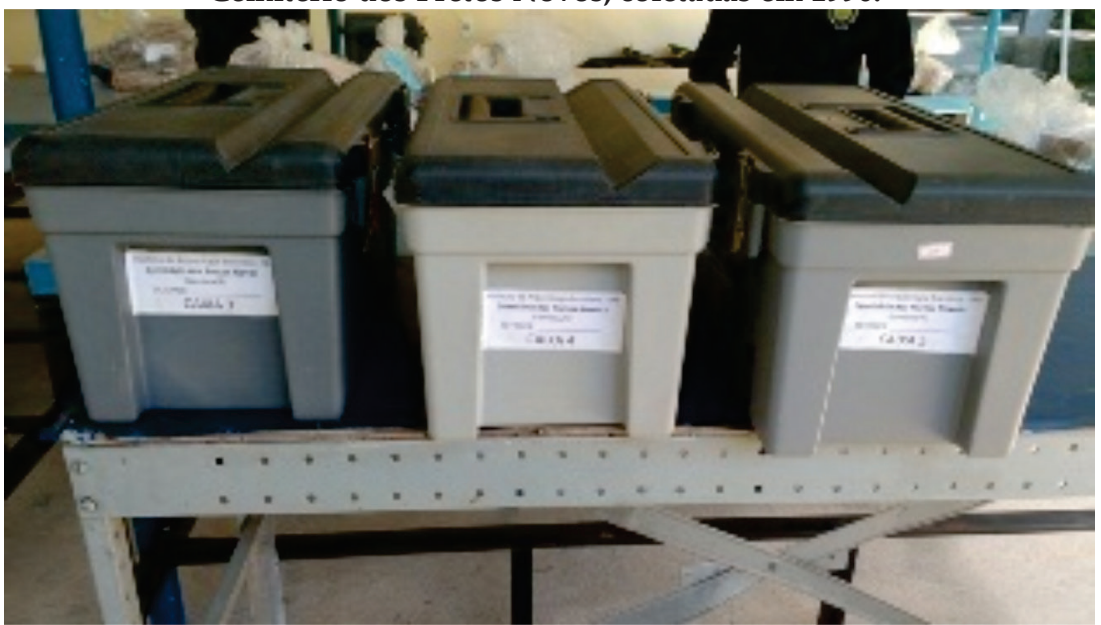

Foto: Tirada por Simone Vassallo.

As práticas dos arqueólogos em questão repousam num paradoxo muito controverso na contemporaneidade, o de tratar como objetos de ciência osvestígios humanos de grupos submetidos a intensos processos de dominação, como o colonialismo e a escravização. Durante a expansão colonial, entre meados dos séculos XIX e XX, a antropologia física e outras ciências afins coletavam e analisavam os vestígios humanos e artefatos materiais desses mesmos povos e através deles atestavam a sua inferioridade e o seu primitivismo (VÉRANT, 2012). Assim tiveram origem coleções arqueológicas e setores de antropologia biológica em vários museus, inclusive no Brasil (SCHWARCZ, 1993; SÁ; SANTOS; CARVALHO; SILVA, 2010). Atualmente, através das inúmeras críticas pós-coloniais ao processo de objetificação desses indivíduos, a presença de vestígios humanos em laboratórios pode representar uma séria afronta à dignidade humana (BROWN, 2008) e muitos restos mortais são alvos de pedidos de repatriação. Contudo, eles não desaparecem dos laboratórios e museus, mas são ressignificados. Não mais engajados numa perspectiva evolucionista, eles se propõem a fornecer importantes informações sobre os povos dos quais se originam, o que não apaga as suas contradições (BROWN, 2008).

Através da atuação dos arqueólogos, temos um primeiro "ponto de passagem obrigatório" (CALLON, 1986), que consiste num novo enquadramento ou definição de um acontecimento, realizado por um 
determinado grupo de atores, que cria uma forma específica de associação uma rede - entre humanos e não humanos. Esse grupo de atores - no nosso caso, os arqueólogos -, ao determinar que aquele local é o sítio arqueológico Cemitério dos Pretos Novos, envolve os mundos social e natural e suas respectivas entidades de uma certa maneira, estabelecendo suas identidades e os vínculos entre elas.

A partir de então, definidas como pertencendo ao Cemitério dos Pretos Novos e classificadas como integrando um sítio arqueológico, as ossadas são retiradas de um determinado contexto anterior - o da terra em que se encontravam - e passam a integrar uma nova rede de atores, humanos e não humanos, composta por arqueólogos, laboratórios científicos, representantes do poder público ligados à cultura e ao patrimônio, instituições de pesquisa e pesquisadores, a família Guimarães e sua casa. É a partir dessa classificação inicial que as ossadas começam a seguir uma determinada trajetória e a ter uma certa "vida social" (APPADURAI, 2008). É dentro dessa rede, e somente dentro dela, que as ossadas adquirem esse significado. Afinal, quantos ossos já não teriam sido encontrados por vizinhos e operários, em obras públicas ou privadas na região, sem que tal enquadramento fosse realizado?

Uma vez identificado e classificado, o "achado" desperta um grande interesse dos representantes do poder público mais diretamente envolvidos. O Diretor Geral do DGPC, em ofício de 15/02/96, ressalta "a importância histórica que essa descoberta representa para a memória da cidade do Rio de Janeiro". A arqueóloga Eliana Teixeira elabora um projeto de pesquisa para que uma verdadeira prospecção arqueológica seja realizada na residência. A Secretária de Cultura concorda em arcar com as despesas das sondagens, e o IPHAN e o DGPC estreitam as suas parcerias com o intuito de melhor garantir a preservação e as pesquisas relacionadas ao sítio.

A nova prospecção arqueológica nunca veio a ser realizada e nenhuma outra ação dos órgãos públicos mencionados foi efetuada. Mas os resultados do primeiro salvamento são divulgados nos trabalhos de Lilia Cheuiche Machado. Através de análise de biologia esqueletal, associada às pesquisas arqueológica e histórica, Machado afirma que o local é de fato o Cemitério dos Pretos Novos e traz algumas informações adicionais:

“Através do resgate emergencial e das pesquisas históricas
efetuadas foi possível identificar o local como o antigo
Cemitério dos Pretos Novos (1770 a 1830), lugar destinado aos 
enterramentos de escravos recém-chegados que morriam logo após o desembarque no Rio de Janeiro". (MACHADO, 2006, p.1).

Segundo ela, "os padrões de 'mutilações' dentárias analisados na amostra do sítio Cemitério dos Pretos Novos indicam a procedência africana dos indivíduos ali sepultados". Seu trabalho conclui que "predominaram jovens do sexo masculino (18/25 anos), seguindo-se adultos e indivíduos na meia idade, em menor proporção. Identificamos, também, adolescentes entre 12 e 18 anos e crianças entre 3 e 10 anos" (MACHADO, 2006, p.11).

Lilia Cheuiche também descreve que "os corpos nus eram envoltos em esteiras, amarradas por cima da cabeça e por baixo dos pés. O rito era sumário: de forma descuidada, sem abrir covas, jogavam um palmo de terra sobre cada um deles, lançando-os aos pares". (VARGAS et al., 2001). A autora observa ainda que os corpos enterrados haviam sido queimados: "as fogueiras eram acesas sob os corpos amontoados e, em muitos casos, os envolviam completamente" (MACHADO, 2006, p.11).

Apesar de todas essas afirmações, Lilia Cheuiche é reticente em suas conclusões, devido às más condições do resgate arqueológico: "a natureza da amostra e a condição de fragmentação e mistura dos ossos e dentes avaliados nesse estudo dificultaram conclusões e interpretações" [grifos meus] (MACHADO, 2006, p.12).

Poucos anos depois dos trabalhos de Machado $^{3}$, novos estudos da Fiocruz pretenderam confirmar as pesquisas anteriores e declararam que as ossadas eram de fato de africanos e que eram procedentes de diferentes regiões do continente (BASTOS, 2010). Atualmente, uma equipe de pesquisadores da Universidade de Leicester, na Inglaterra, está dando início a uma importante pesquisa sobre o genoma do povo brasileiro, tendo por base essas mesmas ossadas.

Os arqueólogos e demais representantes do poder público envolvidos, cada qual ao seu modo, atuam como porta-vozes das ossadas, falando por elas e atribuindo-lhes uma identidade própria, a de pertencentes ao sítio arqueológico Cemitério dos Pretos Novos. Ao mesmo tempo, atribuem a si

\footnotetext{
${ }^{3}$ Lilia Cheuiche Machado faleceu em 2005, levando a uma interrupção provisória das pesquisas sobre as ossadas.
} 
próprios um papel e uma identidade, o de responsáveis pela sua proteção e por revelar cientificamente quem, de fato, elas são.

Os arqueólogos e demais profissionais ligados a instituições do Estado, seja de pesquisa, seja de políticas de preservação patrimonial, têm legitimidade e prestígio para poder nomear e fazer valer as suas próprias classificações, conferindo uma chancela "científica" às ossadas encontradas e determinando os seus novos rumos. Aos poucos, ainda que apoiada em resultados inconclusivos, essa identidade se estabiliza.

\section{2) Do global ao local e vice-versa}

As representações objetificadas das ossadas não são as únicas possíveis, e as ações dos arqueólogos e representantes do poder público certamente não se esgotam nelas. Em novembro de 2001, mês da consciência negra, o então diretor do Arquivo Geral da Cidade do Rio de Janeiro, Antônio Carlos Austregésilo de Athayde, fascinado com a descoberta arqueológica, organiza a exposição "Africanos Novos na Gamboa, um portal arqueológico" e o "Seminário Cotas da Escravidão". Ambos os eventos giravam em torno da descoberta do Cemitério dos Pretos Novos, com o intuito de lhe dar visibilidade e ampliar os debates sobre o sítio. O seminário era fortemente influenciado pela Conferência Mundial contra o Racismo, Discriminação Racial, Xenofobia e Intolerância Correlata, promovida pela ONU, em Durban (África do Sul), em 2001. Ela contara com diversos representantes do movimento negro brasileiro, que tiveram um papel fundamental na definição de um dos principais pontos debatidos na Conferência, querepousa na importância de

\footnotetext{
“todos os países da região das Américas e de todas as outras áreas da Diáspora africana, reconhecerem a existência de sua população de descendência africana e as contribuições culturais, econômicas, políticas e científicas feitas por esta população e a reconhecerem a persistência do racismo, discriminação racial, xenofobia e intolerância correlata que os afeta especificamente...". (CONFERÊNCIA, 2001, p.16).
}

Além disso, a Conferência declara a escravização e o tráfico transatlântico negreiro como crimes contra a humanidade.

A primeira mesa-redonda organizada por Athayde intitulava-se "PósDurban, a visão institucional" e era composta por 7 importantes lideranças 
do movimento negro que haviam participado do encontro da $\mathrm{ONU}^{4}$. Com isso, Athayde consolida a presença de mais um relevante grupo de atores que se organiza em torno das ossadas: os ativistas negros.

O Seminário Cotas da Escravidão se inspira não apenas nas recentes decisões da ONU, mas num contexto internacional mais amplo de crescente publicização e politização das memórias da escravidão e do tráfico negreiro. Desde o início dos anos 1990, intelectuais africanos se dedicavam a dar visibilidade a importantes locais da costa africana relacionados ao tráfico transatlântico negreiro (ARAUJO, 2014). Suas ações inspiraram a UNESCO que, em 1996, criou o projeto Rota do Escravo, com o intuito de patrimonializar esses mesmos locais, desenvolver o turismo de memória e sensibilizar a opinião pública sobre os efeitos produzidos pela escravidão negra. Também nos anos 1990, ativistas afro-americanos começaram a redescobrir e a dar visibilidade a antigos cemitérios de escravos nos EUA, transformando os locais em memoriais onde cultuam os seus ancestrais. O African Burial Ground de Nova York, que ganhou mais proeminência, mobilizou inúmeros ativistas, deu origem a uma das maiores escavações arqueológicas urbanas dos EUA e foi transformado em monumento nacional, num processo permeado por intensos conflitos (BARRET, 2014; BLAKEY, 2010; HARRINGTON, 1993; MCCARTHY, 1996). As reivindicações em torno das ossadas dos cemitérios de escravos nos EUA ocorrem num contexto mais amplo em que os vestígios humanos de povos antes colonizados são alvos de inúmeros pedidos de repatriamento por parte dos que se consideram seus descendentes.

Portanto, em 2001, havia um contexto de forte mobilização internacional em torno de um novo enquadramento da escravização que procurava desnaturalizá-la e denunciá-la (VASSALLO, 2017). Ao mesmo tempo, buscava-se valorizar a presença e a participação dos africanos e afrodescendentes na formação das sociedades americanas. Tentava-se retirar os escravizados da invisibilidade e da condição de objetos em que

\footnotetext{
${ }^{4}$ São elas: Joel Rufino dos Santos (Subsecretário de Estado de Direitos Humanos), Benedita da Silva (Vice-Governadora do Estado do Rio de Janeiro), Marcelino Germano (Subsecretário de Acompanhamento Operacional do Gabinete do Prefeito da Cidade do Rio de Janeiro), Carlos Moura (Presidente da Fundação Cultural Palmares), Edson Santos (Vereador da cidade do Rio de Janeiro), Ivanir dos Santos (Presidente do Centro de Articulação de Populações Marginalizadas), Edna Roland (Presidente da Fala Preta/Organização de Mulheres Negras).
} 
eram historicamente colocados - seja como mercadorias do tráfico, seja como de interesse científico - , e atentar para a sua humanidade. Ativistas negros e pesquisadores procuravam converter o termo "escravo" - que conota passividade e naturaliza a sua condição - em "escravizado" (BARRETT, 2014), ressaltando o intenso processo de dominação a que eram submetidos. As ossadas dos escravizados deveriam seguir a mesma lógica: deixar de serem consideradas (somente) pelo seu interesse científico e serem tratadas como cadáveres humanos dignos de receberem ritos fúnebres. Assim, ossadas e demais vestígios humanos são investidos de "novos poderes" (VÉRANT, 2012) e se tornam poderosos símbolos de diferentes formas de dominação que se exercem tanto no passado quanto no presente, bem como das lutas de resistência. Por isso, as ossadas são reivindicadas por diversos ativistas negros, que as veem como "bens inalienáveis" (WEINER, 1992), e para quem elas possuem uma relevância moral e política nas lutas do presente contra a desigualdade racial (PALMIÉ, 2010). Durban representava um ponto de inflexão fundamental nesse movimento, estabelecendo analogias com o holocausto judeu e classificando a escravização como um holocausto negro. Ainda que boa parte das reivindicações veiculadas durante a Conferência já fizesse parte da agenda política do movimento negro brasileiro, o reconhecimento de uma instituição internacional com o poder e o prestígio da ONU impacta fortemente o imaginário e as ações dos representantes do poder público local, exercendo uma influência que só os militantes negros locais dificilmente conseguiriam obter.

Athayde, que tinha relações com o mundo do samba e da cultura afro-brasileira, foi fortemente influenciado por todo esse processo. Para o seminário Cotas da Escravidão, convidou também importantes pesquisadores norte-americanos dedicados à história da escravidão e da diáspora africana, como Paul Lovejoy e Mary Karash, e organizou mesas-redondas sobre o projeto Rota do Escravo da UNESCO e sobre o African Burial Ground de Nova York. O seminário também contou com apresentações de arqueólogos do IAB e do IPHAN, de Eliana Teixeira, de Lilia Cheuiche, do Diretor do DGPC, de professores e pesquisadores universitários e do próprio Athayde, entre outros.

Nesse momento, a ênfase de diversos pesquisadores que participam do seminário recai na valorização da presença africana e afrodescendente na formação da cidade e do país, até então, invisibilizada em boa parte dos relatos oficiais. Em sua pesquisa, Lilia Cheuiche declara que a descoberta do Cemitério dos Pretos Novos "revelou a importância do local para a 
memória e identidade cultural da cidade do Rio de Janeiro e da população afrodescendente" e pode favorecer "uma melhor compreensão dos aspectos da diáspora involuntária africana ao Brasil" (MACHADO, 2006, p.1). Em sua fala, a arqueóloga do IPHAN, Rosana Najar, afirma que "repensar a preservação, inclusive a de nosso patrimônio arqueológico, tentando incorporar o passado dos vários sujeitos que formaram o Brasil, é apontar para a construção de um outro futuro possível, é pensar um outro projeto de país e de sociedade" (NAJAR, 2001). Assim, os mesmos pesquisadores que dão um tratamento objetificado às ossadas, classificando-as, escrutinandoas, ensacando-as e considerando-as como artefatos da cultura material, ressaltam a sua condição humana e proclamam o respeito aos seus descendentes e ao seu legado cultural.

O encerramento do evento ocorreu com a "Cerimônia marcos da escravidão", que fixava uma placa na parede externa da residência da família Guimarães sinalizando a presença do sítio arqueológico e sua importância histórica. Podemos dizer que, tendo por referência as ossadas, Athayde traduziu localmente as tendências que ocorriam no plano internacional, contribuindo para a ressignificação das mesmas. Poucos anos depois, Athayde junto com alguns pesquisadores e ativistas negros convenceram o Prefeito a promulgar o Decreto n. 24.088, de 5 de abril de 2004, que criava o Portal dos Pretos Novos, "onde serão referenciados e homenageados os negros que não resistiram à vinda da África e, ao falecerem, foram enterrados no secular e desconhecido Cemitério dos Pretos Novos". Essa iniciativa se inspirava no projeto Rota do Escravo, da UNESCO, que criava ou restaurava portais, monumentos e patrimônios diretamente relacionados ao tráfico negreiro. O Prefeito tinha interesse nessas ações de promoção da localidade, pois desenvolvia nesse momento o Plano Porto do Rio de revitalização da zona portuária. No entanto, as ações preconizadas no Decreto nunca saíram do papel.

Num outro sentido, o Seminário Cotas da Escravidão coloca as ossadas num plano internacional, na medida em que as põe em contato com importantes pesquisadores norte-americanos dedicados aos estudos sobre a diáspora africana. Sua rede então se amplia e transcende as fronteiras da nação, pois dela passam a fazer parte locais como o African Burial Ground de Nova York, monumentos do projeto Rota do Escravo da UNESCO e seus respectivos pesquisadores ou defensores. Desde então, pesquisadores estrangeiros e a mídia internacional visitam com frequência o sítio arqueológico. 
O seminário de 2001 também teve um papel central na atuação da família Guimarães, pois foi assim que seus entes compreenderam a real importância "científica" da descoberta que haviam realizado sob os seus pés e selaram laços com pesquisadores brasileiros e estrangeiros que nunca mais se desfizeram. Sua casa passou a ser crescentemente invadida por uma legião de jornalistas, pesquisadores, militantes negros e demais curiosos.

\section{3) 0 Cemitério dos Pretos Novos como um holocausto negro}

Durante o processo de estabilização do fato científico, cada entidade pode se submeter à identidade proposta pelo projeto inicial ou, ao contrário, "recusar a transação e definir de outra maneira a sua identidade, seus objetivos, projetos, orientações, motivações ou interesses" (CALLON, 1986, p.10). Assim têm início as controvérsias.

A família Guimarães nunca concordou com o papel que lhe foi atribuído inicialmente pelos arqueólogos que fizeram o salvamento das peças. No entendimento dos membros da família, eles próprios é que são responsáveis pelas ossadas e delas devem cuidar, entendendo o seu trabalho como uma missão. Eles acusam os arqueólogos de não levar em conta a sua própria atuação em todo esse processo e de não lhes divulgar os resultados das pesquisas conduzidas sobre as ossadas por eles encontradas. Além disso, desqualificam a pesquisa dos arqueólogos afirmando que o estado de deterioração dos ossos escavados em 1996 inviabiliza qualquer resultado conclusivo. A família Guimarães legitima e justifica as suas próprias ações em torno da ideia de luta pela memória e pelo respeito dos Pretos Novos ali enterrados e desqualifica a atuação dos arqueólogos de 1996 e dos da Fiocruz por não se engajarem nela. Como parte dessa luta, acreditam que a história dos Pretos Novos não deve ficar confinada ao mundo da academia e deve ser do conhecimento de todos.

Com esse intuito, compraram o imóvel contíguo à sua casa e lá criaram o Instituto dos Pretos Novos (IPN), em 2005, abrindo o espaço à visitação. Desde então, procuram divulgar as suas próprias narrativas sobrea história que encontraram enterrada sob os seus pés através de palestras, debates e atividades artísticas voltadas para os Pretos Novos, a escravidão e a cultura afro-brasileira. No seu espaço, atribuem os seus próprios sentidos a si mesmos e aos ossos do subsolo que nem sempre coincidem exatamente com o dos arqueólogos que fizeram o salvamento em 1996.

Apesar de a família Guimarães ter participado ativamente dos eventos 
de 2001 organizados por Athayde e ter sido posta a par das diversas ações internacionais relacionadas à escravidão, é somente em 2010 que as analogias com o holocausto negro começam a lhe fazer sentido. Ao longo dos anos 2000, o Brasil adotou diversas políticas de ação afirmativa ${ }^{5}$, que ampliaram para vários setores da sociedade os debates e representações sobre a escravidão e seu legado, tornando-os mais accessíveis à população em geral.

Também nos anos 2000, uma série de ações internacionais começaram a trazer a público as novas possibilidades de representação da escravização como crime contra a humanidade. Na costa africana ocidental, importantes pontos do projeto Rota do Escravo tornaram-se alvo de intensas visitações turísticas, sobretudo de afro-americanos que buscam refazer simbolicamente o trajeto daqueles que consideram seus ancestrais, os africanos escravizados. Apesar de alguns desses locais terem a sua autenticidade contestada, isso não foi suficiente para frear o processo de visitação e alguns se tornaram alvo de peregrinação de importantes lideranças políticas que ali pediram perdão pelo envolvimento pregresso de suas nações com o tráfico transatlântico negreiro ${ }^{6}$. É também a partir dos anos 2000 que vários memoriais e museus sobre a escravidão ou sobre a diáspora africana são criados em Londres, Liverpool, Nantes, Bordeaux, Washington, entre outras localidades. Essas ações comemorativas, ainda que criticadas por diversos autores pela relação de descontinuidade entre passado e presente e por não atingirem as estruturas de dominação contemporâneas (TROUILLOT, 2000; PALMIÉ, 2010; CHIVALLON, 2012), também divulgam para o grande público as ideias preconizadas em Durban que até então circulavam de modo mais restrito.

Influenciada pelos novos debates internacionais e locais sobre a escravidão, Merced Guimarães elabora progressivamente um novo entendimento para o Cemitério dos Pretos Novos: o de que ele é testemunho

\footnotetext{
${ }^{5}$ Dentre elas, podemos mencionar as cotas para o ingresso de estudantes negros em universidades públicas, a possibilidade de titulação da terra aos remanescentes de quilombos, a lei 10.639, que torna obrigatório o ensino da história e da cultura africana e afrodescendente nas escolas, o Estatuto da Igualdade Racial.

${ }^{6}$ Tal foi o caso de Bill Clinton quando Presidente da República nos EUA; Tony Blair quando Primeiro Ministro britânico, Luís Inácio da Silva, quando Presidente da República no Brasil, e o Papa João Paulo II, entre outros.
} 
de um crime contra a humanidade, um holocausto negro. As políticas de ação afirmativa e de promoção da cultura afro-brasileira dos anos 2000 impactaram diretamente nos rumos do IPN: em 2010, graças aos diversos editais voltados para a promoção da cultura popular e afro-brasileira, o instituto se transforma num Ponto de Cultura ${ }^{7}$ destinado à promoção da história e da memória dos africanos e seus descendentes, e também obtém verba para construir o Memorial dos Pretos Novos. Assim, todo o espaço do instituto e as ações que ele promove são reelaborados a partir dessa nova chave interpretativa. Ao operar essa mudança, Merced Guimarães não só traduz para o memorial os seus próprios entendimentos sobre o sítio arqueológico, como também impõe ao seu modo a identidade de outros atores e define quem eles são e o que eles "querem" (CALLON, 1986), com a ajuda de vários dispositivos.

Num espaço de cerca de $50 \mathrm{~m}^{2}$, o memorial ocupa uma das salas do IPN e é composto por vários elementos: cerca de 8 painéis, de aproximadamente $1 \mathrm{~m}$ de altura, que reproduzem gravuras de africanos no Brasil, realizadas por pintores viajantes do século XIX; 10 painéis, de aproximadamente 1,5m de largura, contendo explicações textuais e algumas imagens sobre o tráfico transatlântico negreiro, os locais de sepultamento de escravos no Rio de Janeiro e o papel do Instituto dos Pretos Novos em relação ao sítio arqueológico; a reprodução de um tronco de cerca de $2 \mathrm{~m}$ de altura simbolizando um pelourinho, cuja extremidade inferior é pintada de vermelho em referência ao sangue dos escravizados; os nome de batismo de alguns dos africanos que foram ali enterrados, localizados no livro de óbitos do cemitério e pintados na parede de fundo; dois poços de sondagem escavados pelo arqueólogo Reinaldo Tavares, em 2012, com vistas à realização da sua dissertação de Mestrado em Arqueologia pelo Museu Nacional da UFRJ. Os poços expõem fragmentos de ossos humanos atribuídos aos Pretos Novos encontrados nas suas escavações e são encobertos por pirâmides de vidro.

\footnotetext{
${ }^{7}$ Programa do Ministério da Cultura voltado para a promoção da cultura de coletivos culturais de baixa renda ou em situação de vulnerabilidade.
} 


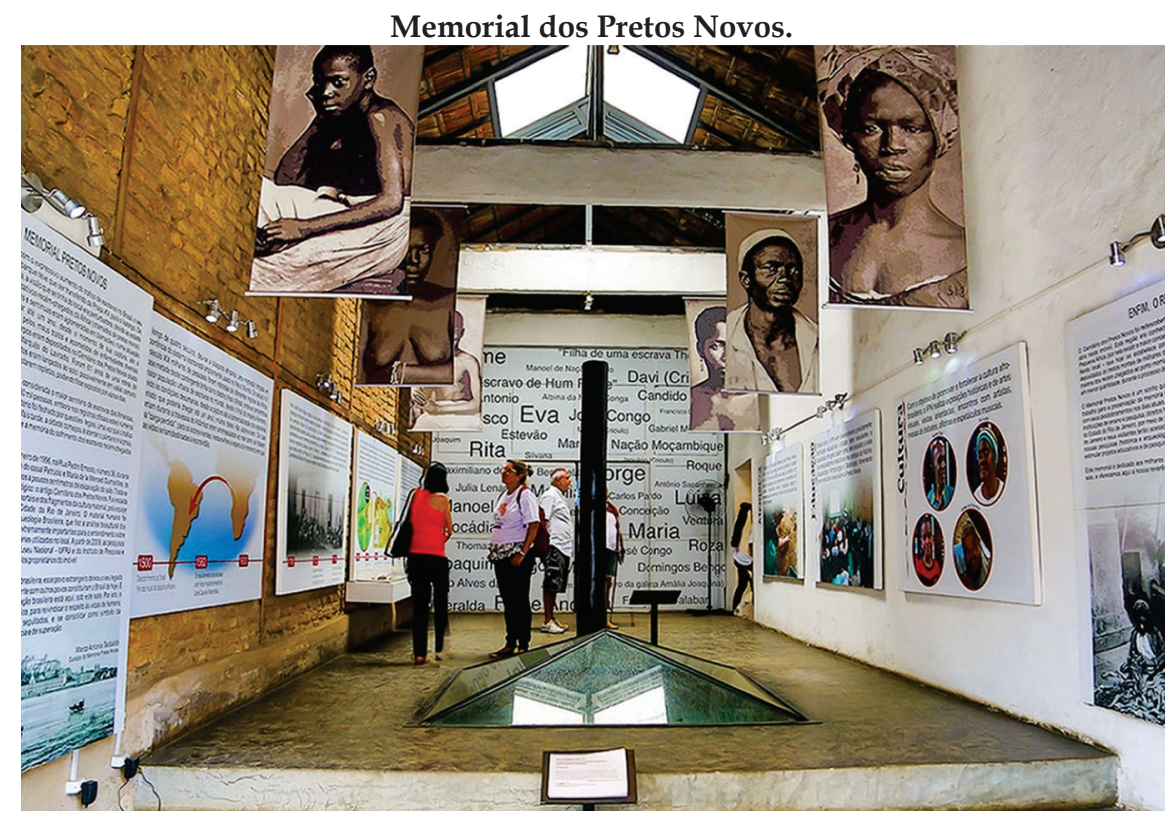

Foto: Arquivo de imagens da CDURP.

Através desses dispositivos, Merced Guimarães traduz ao seu modo a ideia do sítio arqueológico como o testemunho de um holocausto negro e procura estabilizar a sua própria visão dos fatos. No material explicativo produzido pelo IPN, bem como no memorial, temos um processo de vitimização dos escravizados (VASSALLO, 2017) que procura trazer à tona a sua humanidade e denunciar o intenso sofrimento a que foram submetidos. Assim, os painéis que reproduzem as gravuras de africanos e os nomes de batismo dos que foram enterrados no local procuram revelar que, apesar de permanentemente objetificados pela sociedade escravocrata brasileira, os africanos escravizados eram seres humanos e, como tais, dotados de rosto e nome próprio, devendo ser tratados como indivíduos. O pelourinho, pintado de vermelho na extremidade inferior, simboliza o intenso sofrimento a que foram submetidos os que foram ali enterrados. Os painéis explicativos reiteram essas informações. Num deles, intitulado "Memorial Pretos Novos", lemos a seguinte informação:

“A visão que se tinha do local [do mercado de escravos transferido para o Valongo em fins do século XVIII] era perturbadora, devido ao estado em que se encontravam os cativos recém-chegados da África (chamados de Pretos Novos). Figuras esqueléticas, doentes 
e seminuas eram aglomeradas em barracões, numa situação de martírio que podia durar até um ano, desde o momento de sua captura, até a comercialização. Debilitados pelos maus-tratos e acometidos de enfermidades diversas, muitos não resistiam. Seus corpos eram depositados no Cemitério dos Pretos Novos criado naquele mesmo ano [1769] pelo Marquês do Lavradio. Foram 61 anos de uma rotina de sepultamentos em que os mortos eram lançados ao solo, possivelmente em valas comuns, que permaneciam abertas até estarem repletas, podendo ficar expostos por vários dias".

Ao descrever as figuras "esqueléticas", "seminuas" e "doentes" submetidas a intensos maus-tratos nos barracões, bem como a forma com que ocorriam os sepultamentos, temos a denúncia de um tratamento desumano dado a esses indivíduos. As representações que o IPN procura veicular sobre os Pretos Novos podem ser sintetizadas na frase comumente veiculada no seu material de divulgação: "faltou respeito na vida, faltou respeito na morte, faltou respeito na história".

Em sintonia com as novas formas de representação da escravidão e coma emergência da "vítima" como uma categoria político-jurídica (FASSIN; RECHTMAN, 2011; SARTI, 2011), Mercedes Guimarães e demais integrantes do IPN traduzem ao seu modo os debates mais amplos para as representações das ossadas e do seu próprio papel junto a elas. Através dessas afirmações e dos objetos que as veiculam, o IPN redefine a identidade das ossadas que nos são apresentadas como indivíduos - os africanos escravizados - e como vítimas de intensos maus-tratos não só em vida como na morte. Mas define também o que eles "querem". De acordo com os principais integrantes do instituto, o que essas ossadas querem é respeito. Com isso, o próprio IPN constrói para si uma identidade, a da instituição que, enfim, trará o respeito para esses seres humanos tão desrespeitados na vida, na morte e na história, que nunca os levou em conta. Com esse intuito, esse mesmo painel declara que: “o Memorial Pretos Novos é aberto ao público para reivindicar o respeito às vidas de homens, mulheres e crianças que aqui foram sepultados, e se consolidar como símbolo da preservação de uma memória de resistência e superação". Portanto, é através das ações que trazem a público a história do sítio arqueológico e do sofrimento dos que foram ali enterrados que estes obteriam o respeito que, de alguma forma, cicatrizaria as suas feridas e restauraria a sua dignidade humana.

As narrativas sobre a escravidão veiculadas no IPN adquirem ainda mais impacto na medida em que, também em 2011, o Cais do Valongo 
é desenterrado a poucas centenas de metros dali e, graças à atuação de pesquisadores, lideranças negras e representantes do poder público, passa em pouco tempo a simbolizar o local das Américas e mesmo do mundo por onde mais teriam desembarcado africanos escravizados (VASSALLO; CICALO, 2015). O achado ocorre em meio ao Projeto Porto Maravilha de revitalização ${ }^{8}$, que confere uma enorme visibilidade à região portuária e lhe atribui grande interesse por parte do poder público municipal. Em julho de 2017, esse novo sítio é reconhecido pela UNESCO como patrimônio da humanidade, tendo o cemitério como parte da sua "zona de amortecimento". Além disso, tanto o cais quanto o cemitério recebem da UNESCO uma placa de reconhecimento da sua importância para o projeto Rota do Escravo. Juntos, os dois sítios arqueológicos consolidam localmente as novas representações sobre a escravidão a partir de uma perspectiva moral, ou seja, como uma denúncia de um crime contra a humanidade (VASSALLO, 2017), e trazem à luz o fato de o Rio de Janeiro e o Brasil terem sido, respectivamente, a maior cidade e o maior país escravagista em todo o mundo.

$\mathrm{O}$ desenterramento do Cais em meio ao ambicioso projeto de revitalização e a sua possibilidade de reconhecimento pela UNESCO, os crescentes pedidos de reparação para afrodescendentes, bem como as iniciativas internacionais de criação de museus e memoriais sobre o tráfico transatlântico negreiro e a escravidão, dão grande projeção tanto às ossadas dos Pretos Novos quanto a alguns dos atores mais diretamente ligados a elas, como os arqueólogos e a família Guimarães. Nesse contexto, acirram-se as disputas locais em torno das representações da escravidão condensadas nas ossadas encontradas no cemitério.

\section{4) 0 "grito" de Bakhita}

No início de 2017, o arqueólogo Reinaldo Tavares volta a escavar no principal poço de sondagem do Memorial Pretos Novos, dessa vez para realizar a sua pesquisa de doutorado, também pelo Museu Nacional da

\footnotetext{
${ }^{8}$ Trata-se de um ambicioso projeto de requalificação da região portuária, realizado entre 2009 e 2016, que mobilizou alguns bilhões de reais com o intuito de atrair a iniciativa privada e ao mesmo tempo adequar essa região aos grandes eventos que a cidade abrigava nesse período, como a Copa do Mundo de Futebol e os Jogos Olímpicos.
} 
UFRJ. Sua intenção é aprofundar os buracos já abertos em 2012 para ver o que encontra nas camadas inferiores. Sua equipe é composta pela sua coorientadora, alguns outros arqueólogos e técnicos.

Para proceder à escavação, aterra é retirada por níveis e é peneirada pelo menos duas vezes. Na peneiração são encontrados pedaços de ossos, dentes, contas, pedras e material de construção. Depois de peneirada, a terra é colocada em sacos e é descartada. O material encontrado na peneiração é identificado, etiquetado, ensacado, armazenado em caixas e enviado ao Museu Nacional da UFRJ.

Em maio do mesmo ano, em meio às escavações, a equipe é surpreendida pela descoberta de um esqueleto semi-intacto, em posição anatômica, a pouco menos de um metro de profundidade. Até então, os ossos desenterrados e expostos sob as pirâmides de vidro do memorial não tinham mais do que poucos centímetros e encontravam-se fragmentados. Era difícil para um visitante leigo identificá-los como humanos, tornando absolutamente necessárias as explicações adicionais relatadas por integrantes do IPN, guias turísticos e pelos próprios painéis e demais objetos que compunham o memorial.

A identidade e o papel do esqueleto são atribuídos pela equipe de arqueólogos tendo à frente Reinaldo Tavares. Diferentemente dos arqueólogos que fizeram o resgate em 1996, a ênfase de Tavares recai na denúncia do sítio como um crime contra a humanidade, em sintonia com as representações veiculadas no Memorial Pretos Novos. Assim, o esqueleto contribui para a estabilização do sítio arqueológico como um holocausto negro e para a vitimização dos que foram ali enterrados.

Através da observação de características anatômicas, feita a olho nu por uma especialista da equipe, o esqueleto foi identificado como sendo de uma mulher africana de cerca de 20 anos. Ela foi batizada de Josefina Bakhita pelo técnico Andrei Santos que a encontrou. De acordo com Andrei, Bakhita "foi a primeira santa negra católica, ela foi escravizada e ela é padroeira dos cativos escravos. Eu achei uma homenagem justa. Ela passou pelo que eles passaram, ela sentiu o que eles sentiram (...). Se eu me recordo bem, Bakhita significa 'bem-aventurada' em árabe" (entrevista, em 04 de Agosto de 2017).

Para Tavares, Bakhita representa "um grito", "uma denúncia" de todos os horrores que aconteceram naquele local e revela a maneira desumana pela qual os africanos recém-chegados eram tratados na sociedade brasileira escravagista. Ela encarna "o principal símbolo de tudo o que aconteceu ali". Segundo ele, é ela que vai "contar a história dos Pretos Novos" para 
o público, por isso é "bem-aventurada". De acordo com Andrei Santos, ela "se mostra como uma tradução fidedigna do que aconteceu aqui. As marcas físicas da escravidão estão ali, traduzidas naquele esqueleto" (entrevista, 04 de Agosto de 2017).

\section{Bakhita no poço de sondagem do Cemitério dos Pretos Novos.}

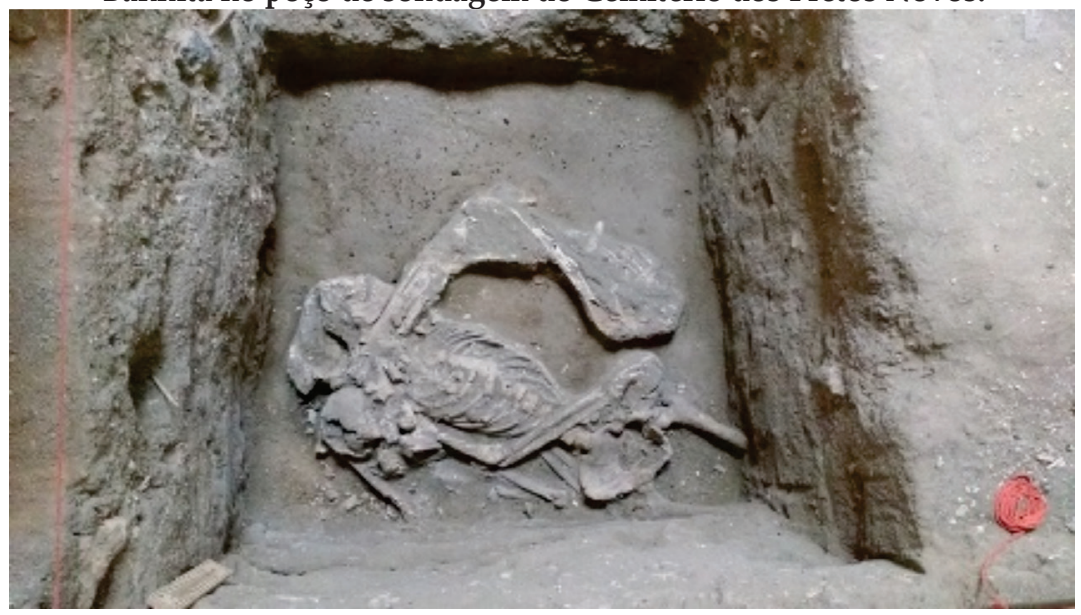

Foto: Foto tirada por Simone Vassallo.

Demais ossos e objetos encontrados nas escavações de 2017 no Cemitério dos Pretos Novos e guardados em caixas que seguem para o Museu Nacional da UFRJ.

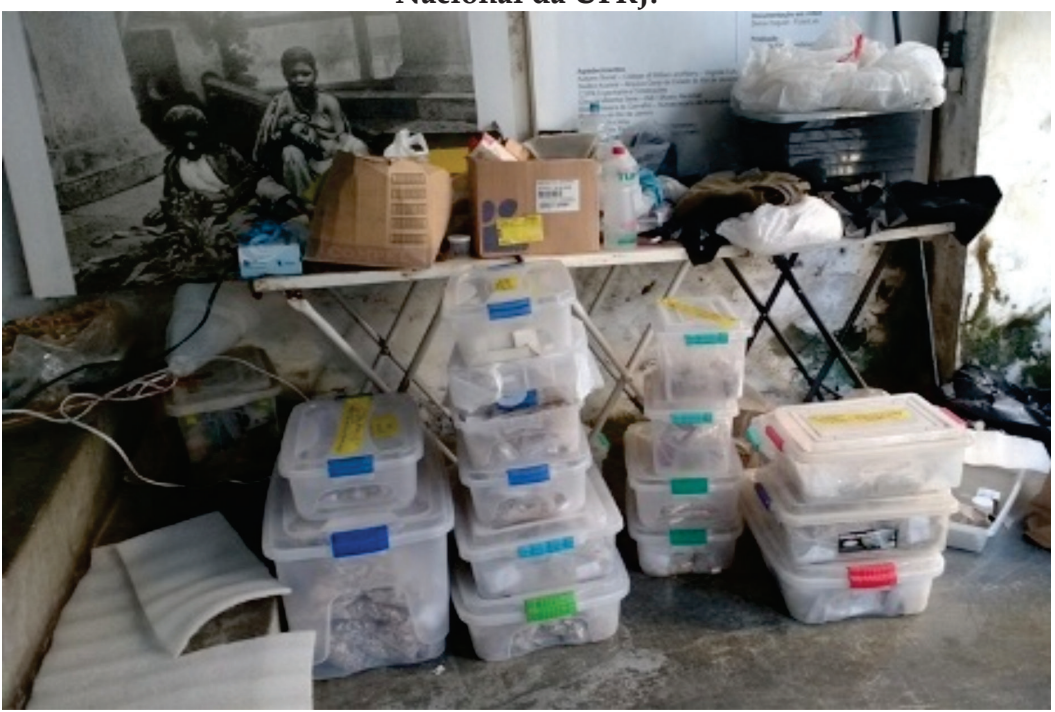

Foto: Foto tirada por Simone Vassallo. 
Como se já possuísse uma existência a priori, somente esperando ser "descoberta", o técnico responsável pelo achado fala numa "revelação": "as poucas pinceladas que eu dei foram revelando os traços da face, da mandíbula, e veio a surpresa: conforme a gente foi passando os pincéis(...) ela foi sendo revelada" (grifo meu, entrevista com Andrei Santos em 04 de Agosto de 2017).

Ainda de acordo com Andrei, a "descoberta" mudou radicalmente os rumos da escavação:

“E foi uma surpresa quando ela estava lá articulada, foi um impacto muito forte. Aí a equipe toda se reuniu e isso mudou o contexto, deu de fato um novo rumo para a pesquisa (...) e ela foi a figura central dessa mudança (...). A gente pode dizer que a pesquisa tem o antes da Bakhita e o depois da Bakhita" (entrevista em 04 de Agosto de 2017).

Assim, para os próprios membros da equipe arqueológica, Bakhita não é apenas uma ossada inerte, ela é dotada de agência. Ela muda os rumos da pesquisa arqueológica e do próprio instituto, ao mesmo tempo em que "grita" para os visitantes todos os horrores que ocorreram ali. Personificada, Bakhita tem nome, sexo, idade, voz, religião e capacidade de ação.

Sua agência e seu poder de revelação se estendem aos estudos da escravidão como um todo e só poderão ser compreendidos aos poucos:

“ela ainda não revelou tudo, ela abriu portas, ela veio literalmente para revolucionar o instituto e as pesquisas bioarqueológicas no contexto do Cemitério dos Pretos Novos e até no contexto da escravidão (...).É claro que nós não temos acesso a tudo o que ela pode nos revelar agora, mas posteriormente, com outros pesquisadores trabalhando em cima, nós vamos ter essas informações(...). E isso é importante para o entendimento de montar esse grande quebra cabeça que é a escravidão brasileira (...). Ela está ali com as informações que nós precisamos". (entrevista a Andrei Santos em 04 de Agosto de 2017).

A intenção inicial de Reinaldo Tavares era a de armazenar Bakhita no Museu Nacional, junto com os demais vestígios e objetos encontrados no local. No entanto, atendendo aos pedidos da família Guimarães e de frequentadores do instituto, Tavares e sua equipe optaram por deixá-la in loco, no próprio contexto do poço de sondagem em que foi encontrada, 
para que seu "grito" possa ser escutado por todos os visitantes do IPN. Para tanto, a equipe arqueológica realiza um trabalho de "consolidação" que consiste em cobrir o esqueleto com produtos químicos que evitem a sua deterioração. Os demais elementos de acondicionamento de Bakhita também deverão ser controlados para impedir a sua erosão, tais como a iluminação, a temperatura e a cobertura de vidro, que irá protegê-la de ameaças externas.

Durante as escavações, a grande quantidade de visitantes ${ }^{9}$ que já frequenta regularmente o Memorial dos Pretos Novos é incentivada a conhecer os poços de sondagem e ser recebida pelos arqueólogos da equipe. Em meio aos objetos que compõem o memorial, como os painéis que apresentam rostos de africanos e os que explicam as suas condições de enterramento no Rio de Janeiro, os seus nomes de batismo pintados na parede de fundo e o pelourinho, os visitantes se deparam com o esqueleto de Bakhita. Posicionados ao redor do poço onde ela se encontra, eles escutam a explicação de Reinaldo Tavares, que lhes apresenta Bakhita e lhes traduz o seu "grito". Nesse momento, é comum os visitantes serem invadidos por uma forte emoção, um sentimento de revolta e terem vontade de chorar. Assim, esta também seria uma das características da sua agência, a de despertar determinados sentimentos no público.

Podemos dizer que os objetos expostos no memorial e as narrativas dos arqueólogos atuam como dispositivos (LATOUR; WOOLGAR, 1997), que conformam o olhar e a sensibilidade dos visitantes e contribuem para a estabilização do fato que se quer afirmar. Esses dispositivos estendem e materializam a hipótese de que aquele local é um sítio arqueológico que testemunha um dos maiores crimes contra a humanidade, um holocausto negro. Eles possuem a habilidade de persuadir, ou seja, de convencer os outros da importância do que fazem e da verdade do que dizem (CALLON, 1986, p.9). Eles atuam como uma moldura (MILLER, 2013) que enquadra os acontecimentos de uma determinada maneira, de modo geralmente inconsciente. Assim, o ambiente material tem uma dupla característica: é ele que torna o fenômeno possível, mas é dele que se deve facilmente esquecer

${ }_{9} \mathrm{O}$ IPN recebe centenas de visitantes por semana, que incluem estudantes do ensino fundamental e médio acompanhados de seus professores, coletivos negros, turistas afroamericanos e turistas em geral, integrantes de passeios organizados a pé pela zona portuária, estudantes universitários, pesquisadores de diferentes áreas, jornalistas, entre outros. 
(LATOUR; WOOLGAR, 1997, p.67). Bakhita expressa e dá materialidade ao imaterial, ou seja, a toda a emoção que se constrói ao seu redor através dos dispositivos criados pelos arqueólogos e pela família Guimarães e seus apoiadores. Juntos, os diferentes integrantes que compõem essa rede estabilizam a identidade de Bakhita, que se torna aquilo que a ela se atribui.

Durante a interação com o público, os textos e objetos colocados em evidência no memorial bem como a atuação dos arqueólogos funcionam como esquemas que codificam a realidade e organizam a percepção, fornecendo certas maneiras de ver e compreender os eventos (GOODWIN, 1994). Através do modo pelo qual classificam as ossadas, os arqueólogos transformam o mundo nas categorias e eventos que para eles são relevantes. Esse sistema de codificação e classificação permite que restos mortais se transformem em peças passíveis de serem exibidas (PIRES, 2017, p.122).

\section{5) Os limites dos porta-vozes e as ambiguidades classificatórias}

O processo de classificação das ossadas e de nomeação de Bakhita não éisento de ambiguidades. Será que seus porta-vozes são de fato representativos? Quem fala em nome de quem? Quem representa quem (CALLON, 1986)? Os ossos efetivamente não falam e Bakhita não "grita". Falar como portavoz é silenciar aqueles em nome dos quais se fala, o que sempre pode ser problemático. Afinal, "é muito difícil falar de modo definitivo em nome de silenciosos seres humanos, mas é ainda mais difícil falar no nome de entidades que não possuem linguagem articulada" (CALLON, 1986, p.14). Independentemente do caráter constrangedor dos dispositivos e do aspecto convincente do argumento, o sucesso nunca está garantido e existem sempre forças inimigas querendo frustrar projeto inicial (CALLON, 1986: 10). A equipe de Tavares e a família Guimarães procuram atuar como porta-vozes das ossadas. Mas os dispositivos que eles criam nem sempre funcionam, e outras possibilidades de entendimento sempre podem ser acionadas. Para que Bakhita possa "gritar", Tavares e os Guimarães têm que realizar uma longa e difícil negociação, nem sempre bem-sucedida, com as ossadas e demais atores envolvidos na rede. O consenso nunca está garantido e pode ser contestado a qualquer momento: a tradução se torna então traição (CALLON, 1986, p.15).

Primeiro, é preciso que a própria Bakhita consinta com o papel que lhe é atribuído. Para tanto, é necessário que ela de fato não se decomponha sob a química protetora que a envolve, a iluminação que lhe dá visibilidade, 
o calor, a umidade e o mofo que sempre ameaçam se instalar sob a sua cobertura de vidro.Só assim Bakhita poderá continuar contando a história que dela se espera. Mofo, umidade, água da chuva, luze erosão são todos fenômenos não controlados que desarrumam as classificações do memorial e revelam o caráter fluido e arbitrário das identidades que se deseja impor.

Segundo, existe um tensionamento entre a perspectiva dos arqueólogos da equipe de Tavares, que queriam seguir com as investigações sobre Bakhita a partir de um "paradigma evidencial" do corpo humano (CROSSLAND, 2009) e enviá-la ao laboratório, e as narrativas dos integrantes do IPN em torno da ideia de uma luta pela memória dos Pretos Novos, que consiste na divulgação dessa história para o grande público, pois se Bakhita é investida do papel fundamental de "revelar tudo o que aconteceu ali", isso não a isenta de disputas sobre como e para quem essas revelações devem ser feitas, muito pelo contrário.

Terceiro, outros integrantes da rede também não aceitam facilmente os fatos propostos. Parte significativa do movimento negro não concorda com as representações atribuídas às ossadas pela equipe de Tavares e pela família Guimarães. Para eles, os ossos ali enterrados são seus ancestrais e, portanto, seus "bens inalienáveis", e uma família "branca" jamais poderá ser a sua porta-voz. Criticam o fato de "brancos" continuarem narrando uma história que consideram lhes pertencer, reproduzindo assim as estruturas de dominação racial. Reivindicando-se como uma "comunidade mnemônica", nos termos de Palmié (2010), eles defendem o direito de poder eles mesmos representar esse passado. Além disso, tecem severas críticas ao processo de vitimização que o memorial procura dramatizar e que, segundo eles, despolitiza o violento processo de dominação dos africanos escravizados e dos que foram ali enterrados. Propõem então o uso do termo "cadáveres", que melhor traduziria o seu posicionamento.

Quarto, os visitantes nem sempre se comportam da forma esperada. Alguns "sentem" e "veem" os espíritos dos escravizados, outros "passam mal" com a sua presença e há também os que conseguem "falar" com eles e receber suas mensagens. Alguns declaram que o pelourinho na verdade é um opá, eixo central de circulação de energia entre o céu, a terra e as divindades, que está presente nos terreiros de candomblé. Um visitante chegou a dizer que o pelourinho personificava Exu, divindade das religiões de matriz africana. Em todas essas circunstâncias, os enterrados deixam de encarnar o papel de vítimas da escravidão e põem em jogo uma miríade de possibilidades interpretativas. 
As ambiguidades classificatórias estão na base da produção dos fatos científicos. No caso do Memorial dos Pretos Novos, temos uma negociação que envolve um jogo de visibilidade e invisibilidade. O que se mostra e o que se oculta? De quem? Para que a "voz" de Bakhita possa ser escutada, é necessária uma negociação entre o que fica visível ao público no memorial e o que segue em caixas para os laboratórios.

Bakhita deve ficar exposta para contar ao público a história dos Pretos Novos, enquanto outros ossos e objetos encontrados ficarão ocultados nos laboratórios científicos e só serão visíveis aos futuros pesquisadores que o solicitarem. Responderão a outras perguntas e contribuirão para a produção de outros fatos científicos. Numa das visitas ao IPN, presenciei os arqueólogos muito envolvidos com um pedaço de terra que continha alguns objetos. Indagavam se um deles seria um osso ou uma pedra. Depois de solucionada a questão, todo o conjunto foi considerado digno de interesse, tendo sido observado, classificado, fotografado e armazenado, para ser futuramente levado ao Museu Nacional. No entanto, a mesma equipe arqueológica que optou por encaminhar esses ossos e demais objetos encontrados espera que Bakhita permaneça in loco para contar a história dos Pretos Novos e denunciar o que houve. Para que o "grito" de Bakhita possa ser escutado, os outros ossos e demais objetos são silenciados nos sacos plásticos e em suas caixas, onde permanecerão no mais profundo anonimato. Temos uma divisão do trabalho em que o público terá acesso a Bakhita, que, por sua vez, não poderá mais ser analisada cientificamente, enquanto os outros ossos e objetos serão ocultados do público e revelados a possíveis futuros pesquisadores. Não contarão a sua história para os visitantes cada vez mais numerosos do IPN, mas poderão vir a contá-la a novos pesquisadores que porventura venham a se interessar por eles. Assim, Bakhita se "humaniza" e se "personifica" na mesma medida em que os demais ossos enviados aos laboratórios são objetificados.

$\mathrm{Na}$ arqueologia, a ambiguidade classificatória é permeada pelo que os próprios arqueólogos chamam de "sensibilidade", ou seja, um processo em que a "imaginação arqueológica" (FABRE; HOTTIN, 2008) preenche os vazios que a ciência não consegue explicar. Como definir e classificar cada um dos objetos encontrados não é uma tarefa simples e nem isenta de conflitos e divergências de interpretações. Será que um objeto é uma pedra ou um osso? Será que é de um homem ou de uma mulher? Será que deve permanecer in loco ou ser encaminhado ao laboratório? Será que deve servir ao público ou aos pesquisadores? Apesar da crença dos cientistas de 
que a imaginação deve ser afastada da observação e do "olhar clínico", pois contém relações ilusórias (CROSSLAND, 2009; FOUCAULT, 1977),

o caráter aparentemente lógico do raciocínio [é] apenas uma parte de um fenômeno bem mais complexo, que Augé (1975) chama de "práticas de interpretação" e que é feito de negociações locais, tácitas, de avaliações constantemente modificáveis, de gestos inconscientes ou institucionalizados. (...) A crença no caráter lógico e direto da ciência emerge no decorrer dessas práticas de interpretação (LATOUR; WOOLGAR, 1997, p.160).

Assim, o caráter objetivo de um fato é a consequência do trabalho dos pesquisadores e não a sua causa (LATOUR; WOOLGAR, 1997, p.200), e é permeado pela sensibilidade e pela imaginação. A equipe de Tavares e a família Guimarães não reproduzem um fato objetivo acerca do intenso sofrimento dos africanos enterrados no sítio arqueológico Cemitério dos Pretos Novos. Eles o produzem, e essa produção só pode ser compreendida no contexto mais amplo e contemporâneo no qual emergem novas formas de representação da escravidão e seus múltiplos tensionamentos. No entanto, as ossadas insistem em escapar às lógicas classificatórias que lhes são predeterminadas, evidenciando a sua fluidez e arbitrariedade.

\section{Conclusão}

Este artigo procurou analisar o processo de conversão simbólica através do qual ossadas humanas se transformaram simultaneamente em objetos de investigação científica armazenados em laboratórios e denúncias de um crime contra a humanidade que devem ser expostas ao público. Seguindo a perspectiva de Bruno Latour e de Michel Callon, procurei compreender como foi construído o fato científico de que o local é o Cemitério dos Pretos Novos e como esse fato influenciou a trajetória das ossadas. Busquei demonstrar que o fato científico do sítio arqueológico não tinha existência a priori e que foram os seus principais atores que o produziram e que estabilizaram as suas definições, através de inúmeros dispositivos. No entanto, os sucessivos processos classificatórios que envolvem as ossadas não são isentos de ambiguidades e são alvos de significativas controvérsias.

Percebemos que a trajetória das ossadas se elabora a partir de uma relação constante entre o local e o global, na qual restos mortais classificados como de africanos podem adquirir alguns sentidos, como os dos arqueólogos de 
1996, os dos arqueólogos de 2012 e 2017, os da família Guimarães e os de integrantes do movimento negro.As disputas classificatórias em torno das ossadas dos Pretos Novos nos remetem a um debate mais amplo sobre as representações contemporâneas da escravidão a partir de uma condenação moral.

Acredito que as ossadas dos Pretos Novos encarnem hoje uma metonímia da escravização que se declina de diferentes maneiras, e por isso são investidas do poder de suscitar narrativas diversas e de mobilizar as pessoas em diferentes formas de atuação, daí as tensões e ambiguidades que pairam em torno delas. Por isso se tornam tão importantes: elas dão materialidade a poderosos símbolos que giram em torno de ancestralidade, afrodescendência, escravização, dominação racial, racismo científico e lutas contra as desigualdades raciais. Expressando os limites entre ser um objeto de pesquisa e vítima de um holocausto negro, as ossadas nos incitam a refletir sobre algumas tensões classificatórias envolvendo restos humanos, e em particular de africanos escravizados, na contemporaneidade.

\section{Referências}

APPADURAI, Arjun (org.).

(2008). A vida social das coisas. As mercadorias sob uma perspectiva cultural. Niterói, EDUFF.

ARANDA, Maria Adoracionet al.

(2014). Las controversias de los materiales culturales delicados: um debate aplazado pero necessario. PH Investigación [en linea], n. 2, p.1-30. Disponivel em: http://www.iaph.es/ phinvestigacion/index.php/phinvestigacion/ article/view/19. Acesso em 10 de Novembro de 2016.

ARAÚJ0, Ana Lúcia.

(2014). Shadows of the slave past: memory, slavery and history. New York and London, Routledge.

BARRETT, Autumn R. D.

(2014). Honoring the ancestors: historical reclamation and self determined identities in Richmond and Rio de Janeiro. Ph. D. Dissertation, College of William and Mary, Department of Anthropology.

BASTOS, Murilo Q. R. et al.

(2010). Da África ao Cemitério dos Pretos Novos, Rio de Janeiro: um estudo sobre as origens de escravos a partir da análise de isótopos de estrôncio no esmalte dentário. Revista de Arqueologia, vol. 24, n. 1, p.68-97.

BLAKEY, Michael.

(2010). Le projet de cimetière africain: un paradigme pour la coopération? Museum, n. 245-246, vol. 62, p.64-71.

BROWN, Michael.

(2008). Actes du Symposium international "Des collections anatomiques aux objets de culte: conservation et exposition des restes humains dans les musées". Musée du Quai Branly. Disponivel em: <http://www.quaibranly. $\mathrm{fr} /$ fileadmin/user_upload/pdf/Version_ Francaise_Symposium_Restes_Humains. pdf>. Acesso em 10 de Outubro de 2015.

CALLON, Michel.

(1986). Some elements of a sociology of translation: domestication of the scallops 
and the fishermen of St Brieuc Bay. In: J. Law; Power, action and belief: a new sociology of knowledge?. London, Routledge.

CARDOSO, E. D.; VAZ, L.F.;ALBERNAZ, M.P.; AIZEN, M.; PECHMAN, R.

(1987). História dos bairros: Saúde, Gamboa, Santo Cristo. Rio de Janeiro, Editora Index.

CHIVALLON, Christine.

(2012). L'esclavage, du souvenir à la mémoire. Paris, Karthala - CIRESC.

CROSSLAND, Zoe.

(2009). Of clues and signs: Dead bodies and their evidential traces. American Anthropologist, 111(1), p.69-80.

FABRE, Daniel; HOTTIN, Christian.

(2008). Préface. In: Claudie Voisenat; Imaginaires archéologiques. Cahier n. 22, Ethnologie de la France. Paris, Editions de la Maison des Sciences de l'Homme.

FASSIN, Didier ; RECHTMAN, Richard.

(2011). L'empire du traumatisme: enquête sur la condition de victime. Paris, Flammarion.

FOUCAULT, François.

(1977). O nascimento da clínica. Rio de Janeiro, Forense Universitária.

G00DWIN, Charles.

(1994). Professional Vision. American Anthropologist, 96 (3), p.606-633.

HARRINGTON, Spencer P. M.

(1993). Bones and bureaucrats? Bew York's great cemetery imbroglio. Archeology, march/april. Disponivel em: http://archive. archaeology.org/online/features/afrburial/. Acesso em 12 de Novembro de 2016.

LATOUR, Bruno; WOOLGAR, Steve.

(1997). A vida de laboratório: a produção dos fatos científicos. Rio de Janeiro, Relume Dumará.

LATOUR, Bruno.

(2012). Reagregando o social. Uma introdução à teoria do ator-rede. Salvador / Bauru, EDUFBA, EDUSC.
MACHAD0, Lilia Cheuiche.

(2006). Sítio Cemitério dos Pretos Novos: análise biocultural. Interpretando os ossos e os dentes humanos. Boletim do Instituto de Arqueologia Brasileira (IAB), n. 12.

MCCARTHY, John P.

(1996). Who owns these bones? Descendant communities and partnerships in the excavation and analysis of historic cemetery sites in New York and Philadelphia. Public Archeology Review, vol. 4 (2).

MILLER, Daniel.

(2013). Trecos, troços e coisas. Estudos antropológicos sobre a cultura material. Rio de Janeiro, Jorge Zahar.

NAJAR, Rosana.

(2001). Preservação do patrimônio arqueológico: identidade e cidadania. Trabalho apresentado no Seminário Cotas da Escravidão, promovido pelo Arquivo Geral da Cidade do Rio de Janeiro, de 6 a 8 de novembro de 2001.

PALMIÉ, Stephan.

(2010). Slavery, Historicism and the Poverty of Memorialization. In: Susannah Radstone; Bill Schwarz (Eds.); Memory: Histories, Theories, Debates. Fordham University, 2010.

PIRES, Renata da S. Montechiare.

(2017). Museus em transformação. Antropologia e descolonização nos museus de Madrid e Barcelona. Tese de Doutorado apresentada ao Programa de Pós-Graduação em Sociologia e Antropologia (PPGSA) da Universidade Federal do Rio de Janeiro (UFRJ).

SÁ, G. J. S.; SANTOS, R. V.; CARVALHO, C. R.; SILVA, E. C. da.

(2010). Crânios,corpos e medidas: a construção do acervo de instrumentos antropométricos do Setor de Antropologia Biológica do Museu Nacional no fim do século XIX - início do século XX. In: M. C. Maio; R. V. Santos (Orgs.); Raça como questão: história, ciência e identidades no Brasil. Rio de Janeiro, FIOCRUZ.

SARTI, Cynthia.

(2011). A vítima como figura contemporânea. Cadernos CRH. Salvador, vol. 24, n. 61, p. 5161, jan/abril 2011. 
SCHWARCZ, Lilia Moritz.

(1993). O espetáculo das raças: cientistas, instituições e questão racial no Brasil, 18701930. São Paulo: Companhia das Letras.

TAVARES, Reinaldo.

(2012). Cemitério dos Pretos Novos, Rio de Janeiro, século XIX: uma tentativa de delimitação espacial. Dissertação de Mestrado. Departamento de Arqueologia, Museu Nacional, Universidade Federal do Rio de Janeiro.

TROUILLOT, Michel-Rolph.

(2000). Abortive rituals: historical apologies in the Global Era. Interventions, vol. 2 (2), p.171 $-186$.

VARGAS, C.; CARVALH0, E. T. de; MACHAD0, L.C.; CAMPOS, G.N.

(2001). (Pesquisa e textos) Africanos Novos na Gamboa. Um Portal Arqueológico. [Catálogo da Exposição....]. Rio de Janeiro, Prefeitura da Cidade do Rio de Janeiro / Secretaria das Culturas / Arquivo Geral da Cidade do Rio de Janeiro / Departamento Geral de Patrimônio Cultural.

VÉRANT, Jean-François.

(2012). Old bones, new powers. Current Anthropology, vol.53, n. S5.

VASSALLO, Simone Pondé.

(2017). Entre vidas objetificadas e vítimas da escravidão: a trajetória das ossadas do Cemitério dos Pretos Novos, no Rio de Janeiro". Sexualidad, Salud y Sociedad, Revista Latinoamericana, n. 25, p.277-297. Disponivel em: <www.sexualidadsaludysociedad.org>.

VASSALLO, Simone Pondé; CICALO, André. (2015). Por onde os africanos chegaram:o Cais do Valongo e a institucionalização da memória do tráfico negreiro na região portuária do Rio de Janeiro. Horizontes Antropológicos. Dossiê Diásporas, n.43.

WEINER, Annette.

(1992). Inalianable possessions: the paradox of keeping while giving. Berkeley, University of California Press.

\section{Documentos Citados}

Conferência Mundial contra o Racismo, Discriminação Racial, Xenofobia e Intolerância Correlata. 2001. Durban, África do Sul. Disponivel em:<http://www.unfpa. org.br/Arquivos/declaracao_durban.pdf>. Acesso em 02 de Agosto de 2017.

Decreto Municipal n. 24.088 , de 5 de abril de 2004.

Memorando/ DITEC/6a CR/IPHAN, n. 190/96, de Rosana Najar ao chefe da DITEC, em 04/03/96.

Ofício de Eliana Teixeira (DGPC) a Lia Aquino de Carvalho (IPHAN), em 15/01/96.

Ofício C/DGPC n. 19, de Alexander Nicolaeff, Diretor Geral do DGPC, a Cyro Corrêa Lyra, Coordenador Regional da 6a CR/IPHAN, em 15/02/1196

Ofício GAB/6a CR/IPHAN, n. 147/96, de Cyro Illídio Corrêa de Oliveira Lyra, Coordenador Regional da $6^{a}$ CR do IPHAN, a Alexander Nicolaeff, Diretor do DGPC, em 11/03/96

TEIXEIRA, Eliana Carvalho de. 1996. Sítio Cemitério da Camboa. Projeto de pesquisas arqueológicas de salvamento, segunda etapa. Secretaria Municipal de Cultura, DGPC, Divisão de Cadastro e Pesquisa.

\section{Recebido em}

outubro de 2017

\section{Aprovado em}

março de 2018 